\title{
Evaluating the Effect of Adding Sugarcane Bagasse to the Fire Clay Brick's Properties
}

\author{
Amany Micheal ${ }^{1}$, Rania Rushdy Moussa ${ }^{2, *}$ \\ ${ }^{1}$ Center for Advanced Materials, The British University in Egypt, El-Sherouk City, Egypt \\ ${ }^{2}$ Architecture Department, Faculty of Engineering, The British University in Egypt, El-Sherouk City, Egypt
}

Received September 16, 2021; Revised November 8, 2021; Accepted December 13, 2021

\section{Cite This Paper in the following Citation Styles}

(a): [1] Amany Micheal, Rania Rushdy Moussa, "Evaluating the Effect of Adding Sugarcane Bagasse to the Fire Clay Brick's Properties," Civil Engineering and Architecture, Vol. 10, No. 1, pp. 71 - 78, 2022. DOI: 10.13189/cea.2022.100106.

(b): Amany Micheal, Rania Rushdy Moussa (2022). Evaluating the Effect of Adding Sugarcane Bagasse to the Fire Clay Brick's Properties. Civil Engineering and Architecture, 10(1), 71 - 78. DOI: 10.13189/cea.2022.100106.

Copyright $\bigcirc 2022$ by authors, all rights reserved. Authors agree that this article remains permanently open access under the terms of the Creative Commons Attribution License 4.0 International License

\begin{abstract}
Due to the increase in population density, the waste and its by-products produced by industry, housing, and agriculture have increased. Waste accumulation causes several environmental problems and contaminates natural resources such as air, soil, and water. Moreover, it threatens human public health and increases the number of epidemics and medical pandemics. The percentage of organic waste increases daily. Almost $60 \%$ of the waste collected from the housing sector is organic waste, in addition to the agricultural wastes that are also considered organic waste. In developing countries, there are no clear waste management systems. The waste is poorly managed, it is either burned or disposed of in waste dumps improperly. On the other hand, mud bricks are considered a substantial wall building material used in developing countries. This experimental research aims to study the properties of new mud brick prototypes by partially replacing $0.5,1.5$, and $2.5 \%$ of the mud with sugarcane bagasse ( $\mathrm{SCB}$ ), which is considered an organic waste material, to create eco-friendly bricks. This research will use an experimental, quantitative method to test the efficiency of the bricks after partially replacing mud with SCB. These experiments will test the slump, strength, cracks, absorption, and density with different SCB replacement percentages. The research revealed that the compressive strength of the mud bricks suffers a considerable reduction due to the burring of the fibers.
\end{abstract}

Keywords Fire Clay Bricks, Bricks Properties, Organic Waste, Bagasse Fibers, Waste Management

\section{Introduction}

Earth's abundantly available materials make them the most economical and accessible natural materials for making building materials, such as bricks. Earth bricks date back to 10,000 BC in Mesopotamia, making them the world's oldest construction material [1,2]. However, humans quickly discovered that earth alone is insufficient for the manufacture of enduring bricks, and that clay's cohesion properties require a natural binder for composites. For example, the ancient Romans added sand to the clay-water combination to improve workability and prevent excessive shrinkage. Moreover, they added natural fibres like dried grass and straws to further decrease shrinkage cracking [3]. Population growth is always accompanied by land acquisition for the construction of new infrastructure and dwellings. Population growth expands agricultural lands, increasing the percentage of waste disposed of. Large amounts of natural waste, such as fibres, grains, and pulp, are generated accidentally throughout the production and manufacturing processes, and are disposed of in landfills or burned. The accumulation of improperly managed and unmanaged waste has caused serious environmental and long-term problems [1].

In many countries, organic wastes are disposed of by dumping them in landfills, leading to more pollution and negative impacts on the environment $[4,5,6]$. Therefore, 
local researchers focus on recognising the best technology to dispose of organic wastes by recycling and utilising them as raw materials in the production chains of other industries [7-8].

The implementation of agro-waste materials in the construction industry is now on the rise. The applications include insulation boards, brick manufacturing, concrete additives, and cement replacement. The natural fibres involved in the process of manufacturing fibre board that can serve as good insulators include rice husk, sugarcane bagasse, cotton stalk, banana bunch, corn peel, and coconut coir, or a combination of more than one type of natural fibre. The properties of these boards and insulating materials can be found in the work of Zhou [12] and Roushdy [13].

Recently, many studies have addressed the integration of organic fibres into the construction industry, such as the brick industry, as shown in table 1. Organic fibres were used in the construction of fibrous building panels, insulation boards, and cement boards. Several types of solid waste are organic fibres, such as bamboo, coconut, oil palm, date palm, sugar palm, vegetable wastes, and sugarcane. These fibres are cheap, yet they have great recycling potential, as shown in Table 1 [14].

According to previous studies, adding natural fibres to clay bricks has shown an increase in the compressive strength and flexibility of clay bricks [15]. Composite bricks with natural fibres result in a porous structure that improves the acoustic and thermal insulation of the brick $[16,17,18]$.

This research aims to increase the application of fire clay bricks integrated with fibers. In order to achieve this goal, a systematic quantification of its properties and characteristics is required, allowing for an objective assessment of the composite material's reaction to actual conditions. The present study was conducted to examine the main properties of bricks made of a clay-fibre brick mixture and to identify the interaction properties and characteristics of the clay-fibre brick compared with the standards of regular clay brick stated in the Egyptian building code. The research used sugarcane bagasse as the additive fibres in the clay-fibre brick. Sugarcane bagasse was never used in the form of fibres as an additive to clay bricks. It has been added before in the form of bagasse ash, but not in the form of fibers, which is the main contribution of this research.

Table 1. Solid wastes recycling potentials [14]

\begin{tabular}{|c|l|l|}
\hline $\begin{array}{c}\text { Type of solid } \\
\text { wastes }\end{array}$ & Source of waste & Potentials of utilization and recycling \\
\hline $\begin{array}{c}\text { Agro-waste } \\
\text { (Organic) }\end{array}$ & $\begin{array}{l}\text { Sugarcane baggage, sisal, wheat and rice straw, wheat } \\
\text { and rice husk, jute, saw mill waste, cotton stalk, ground } \\
\text { nut shell, vegetable residues }\end{array}$ & $\begin{array}{l}\text { Bricks, particle boards, cement boards, insulation } \\
\text { boards, coir fiber, fibrous building panels, wall panels, } \\
\text { roof sheets, binder, polymer composites, acid-proof } \\
\text { cement, reinforced composites, }\end{array}$ \\
\hline $\begin{array}{c}\text { Industrial waste } \\
\text { (inorganic }\end{array}$ & $\begin{array}{l}\text { Coal combustion residues, construction debris, bauxite } \\
\text { red clay, steel slag }\end{array}$ & $\begin{array}{l}\text { Blocks, bricks, cement, tiles, ceramic products, paint, } \\
\text { concrete, coarse and fine aggregates, wood substitute } \\
\text { products }\end{array}$ \\
\hline $\begin{array}{c}\text { Mining/mineral } \\
\text { waste }\end{array}$ & $\begin{array}{l}\text { Coal washeries waste, aluminum and gold industries, } \\
\text { mining waste tailing from zinc, copper, iron }\end{array}$ & Bricks, tiles, coarse and fine aggregates \\
\hline
\end{tabular}




\section{Sugarcane Bagasse}

Worldwide, sugarcane bagasse is still used for energy generation in industrial ovens, but the bagasse's value has increased remarkably due to its importance as a recycled material. Sugarcane bagasse is used to produce packaging materials and disposable tableware. Moreover, the paper industry has also commenced to replace wood fibres with sugarcane bagasse fibres to produce napkins, toilet paper, and cardboard [9]. Nowadays, sugarcane bagasse is the main feedstock source for bioenergy and biofuel production [10, 19].

These applications show that the use of sugarcane bagasse may represent economic and environmental importance for the sugarcane producing countries [11].

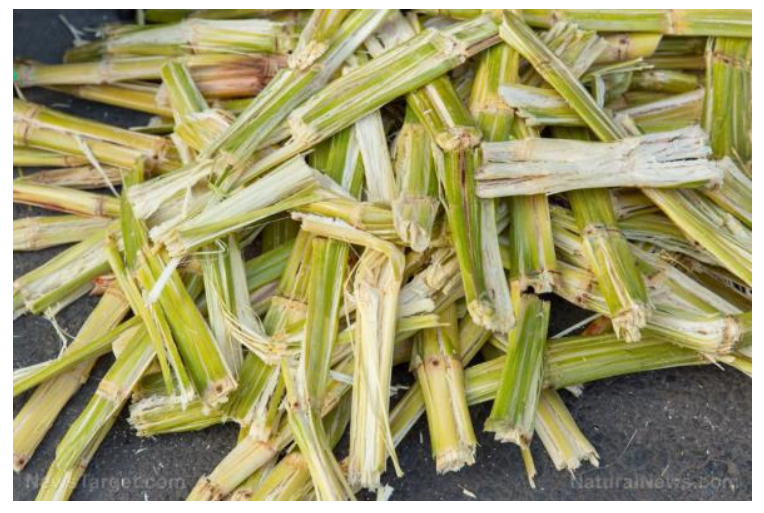

Figure 1. Sugarcane wastes
Bagasse is heterogeneous in terms of size and particle format, as shown in Figure 1, and its three predominant components are cellulose, hemicellulose, and lignin. The chemical components and physical and structural properties of sugarcane bagasse are listed in Table 2 .

\section{Production of Sugarcane Bagasse in Egypt}

Every year, Egypt produces more than 16.8 million tonnes of sugarcane residue [20]. Recycling sugarcane bagasse is a promising field in Egypt as it provides a great opportunity for creating sustainable building materials as well as daily-use products.

The production of sugar was mainly dependent on sugarcane until 1981, when sugar beets were introduced in order to cover the growing local sugar demand. In Menia, Sohag, Qena, Luxor, and Aswan, plantations of cane are concentrated in the Upper Egypt region. According to Hamada [20], the gross cane cultivated in Upper Egypt amounts to approximately 16 million tonnes annually. Therefore, Egypt is considered the largest sugar cane producer, producing 7,5 million tonnes annually among Arab countries, followed by Sudan. Eight sugar cane factories are situated in Egypt, mainly in Upper Egypt, as seen in the graph below, near the crops. The governorates of the sugar cane mills are as follows: "El Menia, Abou Korkas mill; Sohag, Gerga mill; Qena, Nagaa Hamadi, Deshna, and Kous mills; Luxor, Armant mill; Aswan, Edfu, and Komombo Mills."

Table 2. The properties of sugarcane bagasse [10]

\begin{tabular}{|c|c|c|c|c|c|}
\hline \multicolumn{2}{|c|}{ Chemical components } & \multicolumn{2}{|c|}{ Physical properties } & \multicolumn{2}{|c|}{ Structural properties } \\
\hline Components & Composition \% & Diameter $(\mu \mathbf{m})$ & $10-34$ & Tensile strength (Mpa) & $180-290$ \\
\hline Glucose & 19.5 & \multirow{2}{*}{ Length (mm) } & \multirow{2}{*}{$0.8-2.8$} & \multirow{2}{*}{ Young's Modulud (Gpa) } & \multirow{2}{*}{$15-19$} \\
\hline Xylose & 10.5 & & & & \\
\hline Arabinose & 1.5 & \multirow{3}{*}{ Aspect ratio (1/d) } & \multirow{3}{*}{76} & \multirow{3}{*}{ Failure Strain (\%) } & \multirow{3}{*}{$1-5$} \\
\hline Galactose & 0.55 & & & & \\
\hline Lignin & 9.91 & & & & \\
\hline Organo solubles & 2.7 & \multirow{7}{*}{ Moisture content (\%) } & \multirow{7}{*}{49} & \multirow{7}{*}{ Density $\left(\mathrm{kg} / \mathrm{m}^{3}\right)$} & \multirow{7}{*}{$880-270$} \\
\hline Reducing sugars & 1.85 & & & & \\
\hline Uronic acids & 1,91 & & & & \\
\hline Ash & 1.6 & & & & \\
\hline Cellulose & 50 & & & & \\
\hline Total hexoses & 20.04 & & & & \\
\hline Total pentoses & 12 & & & & \\
\hline
\end{tabular}


Several residues are produced from the sugar production process in the mill, as shown in figure 2 . These residues are $30 \%$ bagasse, which is the fibrous remaining material produced from sugarcane chopping and milling. $3.5 \%$ filtered mud/cake obtained through cane juice filtration, $0.4 \%$ furnace ash if bagasse is burned to generate steam and electricity [10].

\section{Sugarcane residues}

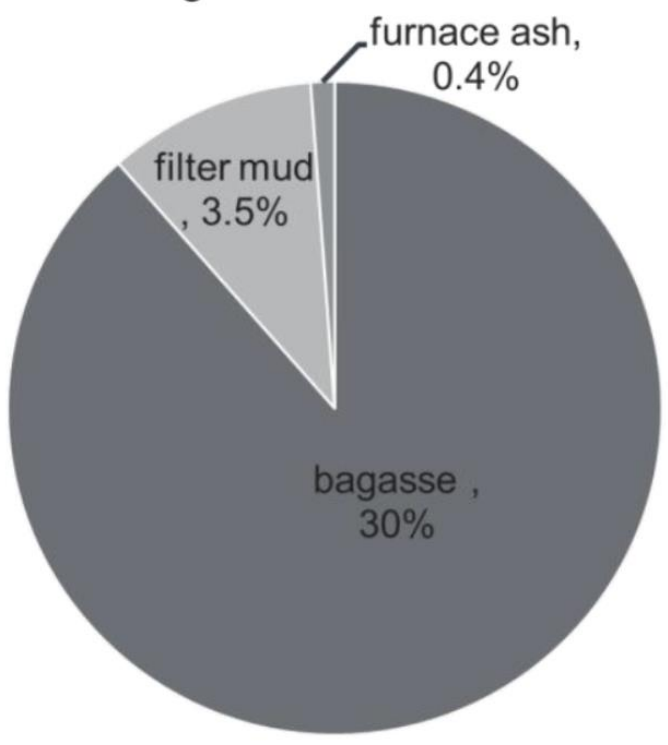

Figure 2. Percentage of sugarcane residues

This research focuses on sugarcane bagasse (SCB) as an organic waste and how to involve it in the construction industry by adding it to the mixture of clay bricks.

\section{Fire Clay Brick}

Due to their characteristics, bricks are among the most adaptable masonry materials. The physical and mechanical characteristics, as well as the colour and aesthetics of the produced brick, may be affected by the burning process. Many studies have been conducted by varying the temperature of the burning process as well as employing rapid and conventional burning methods, although the majority of these studies have focused only on the physical and mechanical characteristics of fired clay bricks.

For example, Dunham et al., for example, examined shorter fire durations in the production of clay bricks, while Dondi et al. investigated the impacts of quick and traditional burning on the physical and mechanical characteristics of clay bricks. As a result, past research hasn't focused on the influence of various temperature levels on the physical and mechanical characteristics of produced clay bricks, including various forms of waste [21].

Many studies have investigated the possible wastes that may be reused or integrated into fired clay bricks due to the high demand for bricks in the construction industry. Previous studies have successfully integrated various forms of waste into fired clay bricks due to the flexibility of the brick structure. It appears to be different from the most typical wastes, such as sludge and fly ash, to bagasse, rice husk, pineapple leaves, cigarette butts, and oil palm fruit bunches [10, 21, 23, 24, 25]. Each study presented different experimental results, as shown in Table 3.

Table 3. Experimental application on integrating wastes with clay bricks

\begin{tabular}{|c|c|c|c|c|}
\hline $\begin{array}{c}\text { Waste } \\
\text { type }\end{array}$ & $\begin{array}{c}\text { Strength } \\
\text { before } \\
\text { fibre } \\
\text { MPa }\end{array}$ & $\begin{array}{c}\text { Percentage } \\
\text { of waste } \\
\%\end{array}$ & $\begin{array}{c}\text { Strength } \\
\text { after adding } \\
\text { the fibre } \\
\text { MPa }\end{array}$ & Source \\
\hline $\begin{array}{c}\text { cigarette } \\
\text { butts }\end{array}$ & 9 & 10 & 6.6 & {$[7]$} \\
\hline $\begin{array}{c}\text { Sugarcane } \\
\text { bagasse }\end{array}$ & 1.5 & 3 & 2 & {$[26]$} \\
\hline $\begin{array}{c}\text { chicken } \\
\text { feathers }\end{array}$ & 1.5 & 3 & 2.5 & {$[26]$} \\
\hline
\end{tabular}

According to Martirena [22], clay brick consists mainly of a mixture of montmorillonite and kaolinite. The oxide compositions of the clay are given in Table 4 .

Table 4. The Chemical composition of clay brick [22]

\begin{tabular}{|c|c|}
\hline Description & Clay \\
\hline $\mathrm{SiO}_{2}$ & 49.56 \\
\hline $\mathrm{Al}_{2} \mathrm{O}_{3}$ & 10.41 \\
\hline $\mathrm{Fe}_{2} \mathrm{O}_{3}$ & 10.73 \\
\hline $\mathrm{TiO}_{2}$ & 0.88 \\
\hline $\mathrm{CaO}$ & 3.82 \\
\hline $\mathrm{MgO}$ & 12.32 \\
\hline $\mathrm{Na}_{2} \mathrm{O}$ & 1.39 \\
\hline $\mathrm{K}_{2} \mathrm{O}$ & 0.22 \\
\hline $\mathrm{P}_{2} \mathrm{O}_{5}$ & 0.07 \\
\hline $\mathrm{MnO}$ & 0.16 \\
\hline $\mathrm{SO}_{3}$ & $<0.10$ \\
\hline $\mathrm{LOI}$ & 9.04 \\
\hline
\end{tabular}

\section{Materials and Experimental Methods}

This section presents the experimental programme adopted in this research to investigate and produce the properties of clay bricks impregnated with sugarcane bagasse (SCB).

\section{Materials Used}

The SCB is abundantly found in the Egyptian juice shops, which find difficulty in dumping it. To conduct the experimental program, ten $\mathrm{kg}$ of SCB were collected from the market and treated manually, as shown in figure 3. 

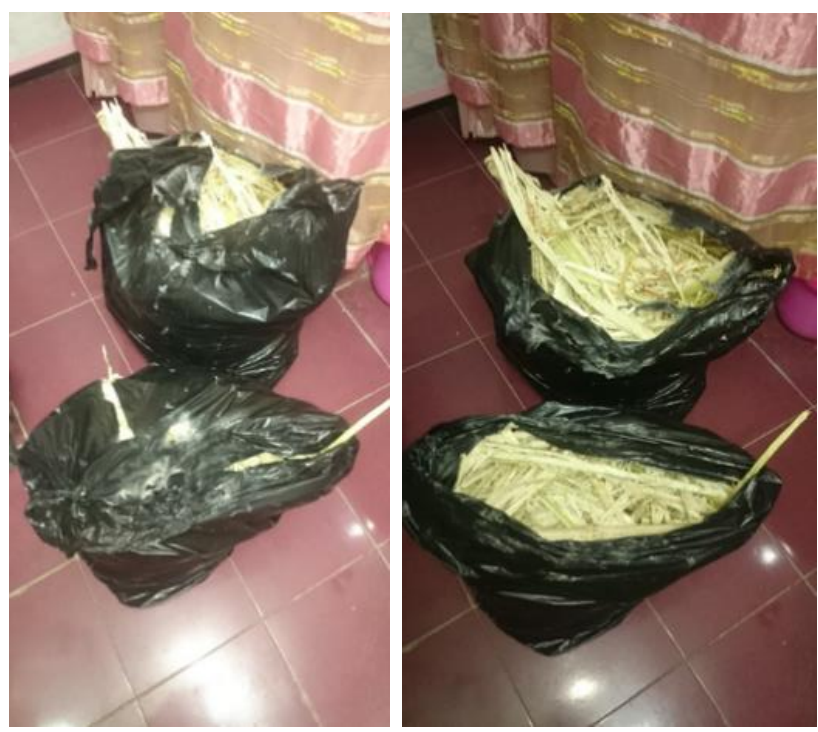

Figure 3. Collected SCB

The treatment regimen starts with soaking it in hot water at $90{ }^{\circ} \mathrm{C}$ for five days, with water changed every day to extract the remaining sugar out of it, Figure 4.

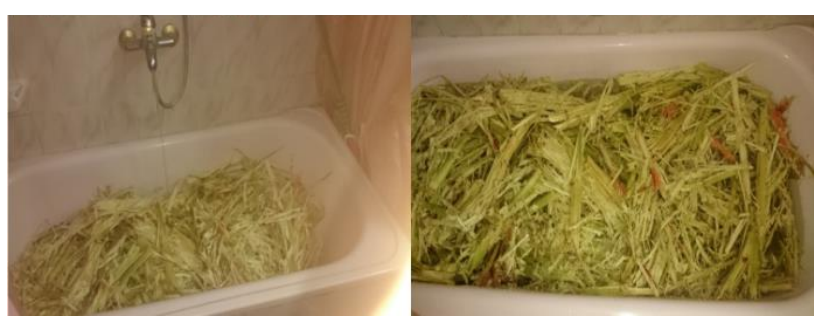

Figure 4. Washing of SCB

Then, drying takes place by exposing it to direct sunlight for 15 days, as shown in figure 5. To ensure complete drying, the SCB is frequently weighed until reaching a constant weight.

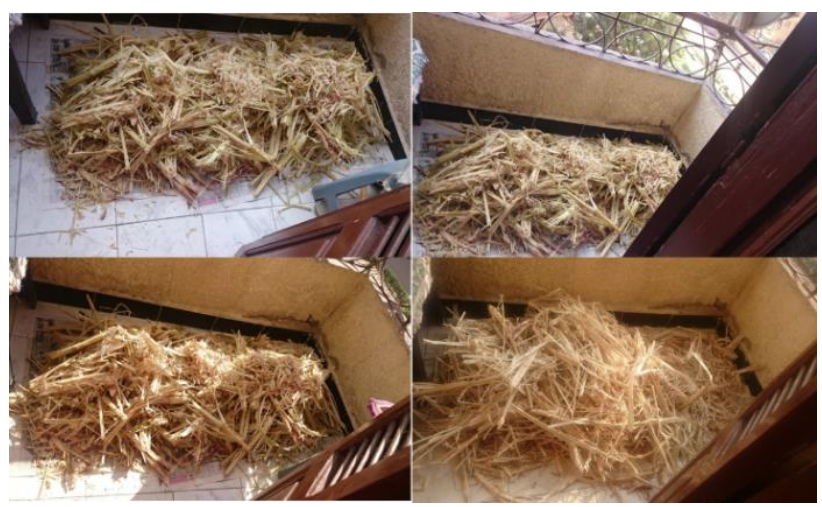

Figure 5. Drying the bagasse using the sunlight

The dried SCB are fragile fibres and have a light unit weight of $0.09 \mathrm{~kg} / \mathrm{m}^{3}$. The fibre diameter ranges from 0.3 to $1.2 \mathrm{~mm}$. Then the dried fibres are cut manually to an 80 $\mathrm{mm}$ length as shown in figure 6 .

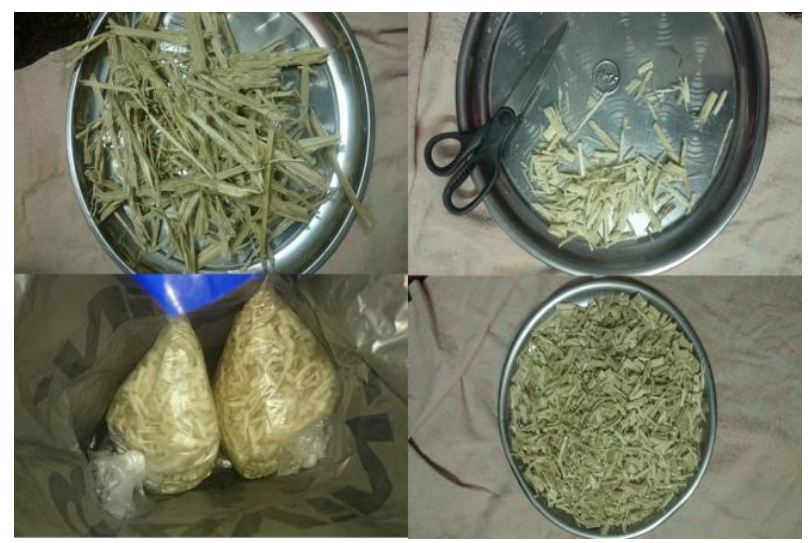

Figure 6. Cutting dried SCB

The treatment procedure is meant to be simple and easy to implement using unskilled labour to facilitate its incorporation into small local brick manufacturing plants.

\section{Manufacturing}

The local practise in Egypt for clay bricks involves the use of two raw materials, clay and sand, in the mix. The mix proportions are 3:1 clay to sand. The chemical composition of the Egyptian local clay, known as Taflah, is given in Table 5 .

Table 5. The chemical composition of local Tafla [15]

\begin{tabular}{|c|c|}
\hline Chemical Component & Percentage \% \\
\hline Silica & $46-60$ \\
\hline Alumina & $10-35$ \\
\hline Lime & $1-10 \%$ \\
\hline Iron Oxides & $4-8 \%$ \\
\hline magnesium oxide & $0-4 \%$ \\
\hline
\end{tabular}

The role of sand is to reduce the volumetric changes of the brick and therefore cracking. Water is added to give plasticity to the mix, at $15 \%$ of the mix weight. The clay brick forms are made of plywood with dimensions of 19.7 $\times 12.3 \times 9.5 \mathrm{~cm}$ as shown in figure 7 .
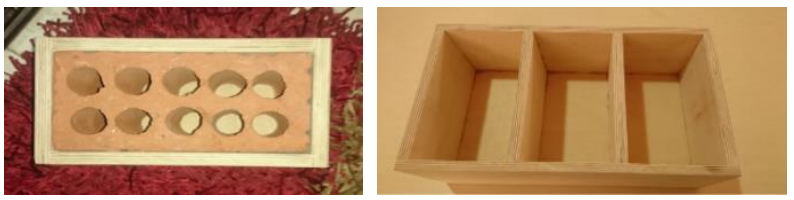

Figure 7. Molding plywood structure

To investigate the effect of adding SCB on clay brick properties, three percentages of SCB by weight are used; $0.5 \%, 1.5 \%$, and $2.5 \%$. Control specimens with $0 \%$ SCB are manufactured for comparison. The ingredients are mixed in a rotary mixer and then cast in wooden forms lined with mineral oil. Three specimens are cast for each SCB percentage, and the average of each property is calculated. The clay bricks are left to dry at the ambient 
temperature for two days. Then, the bricks are removed from the forms and sent to a commercial brick manufacturing plant for burning.

\section{Results}

The burned specimens are moved from the brick manufacturing plant to the laboratory to conduct the experimental programme as shown in figure 8 .

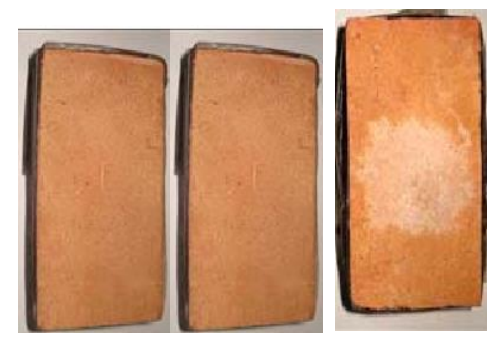

Figure 8. Brick samples

The experiments conducted on the specimens are unit weight, absorption, and compressive strength.

For unit weight determination, all the specimens are weighed using a digital scale, and the volume is determined using the dimensions of the molds. The results of the unit weight of each specimen are given in Table 6 .

Table 6. Unit weight of all specimens

\begin{tabular}{|c|c|c|c|c|}
\hline \% SCB & $\mathbf{0 \%}$ & $\mathbf{0 . 5 \%}$ & $\mathbf{1 . 5 \%}$ & $\mathbf{2 . 5 \%}$ \\
\hline Dry Weight (g) & 1600 & 1590 & 1550 & 1490 \\
\hline Unit weight $\mathbf{~ k g / m 3}$ & 695 & 690 & 673 & 647 \\
\hline \% reduction in weight & -- & $0.72 \%$ & $3.17 \%$ & $6.91 \%$ \\
\hline
\end{tabular}

This concludes that adding SCB with reasonable percentages may lead to a reduction in brick weight that may reach 7\%, which has an impact on the weight of the structure and foundation size.

Table 7. Absorption test results

\begin{tabular}{|c|c|c|c|c|}
\hline \% SCB & $\mathbf{0 \%}$ & $\mathbf{0 . 5 \%}$ & $\mathbf{1 . 5 \%}$ & $\mathbf{2 . 5 \%}$ \\
\hline Dry Weight (g) & 1600 & 1590 & 1550 & 1490 \\
\hline $\begin{array}{c}\text { Weight after 4 hours } \\
\text { immersion (g) }\end{array}$ & 1990 & 1987 & 1980 & 1945 \\
\hline \% absorption & $24 \%$ & $25 \%$ & $28 \%$ & $30.5 \%$ \\
\hline
\end{tabular}

For absorption, the specimens were tested according to ESS 4763/2006 [25]. Table 7 shows the bricks' weight before and after immersion in hot water and the percentage absorption. The increase in absorption is expected due to the hydrophilic properties of SCB. According to ESS 4763/2006 [25], the absorption of normal weather (NW) clay bricks should not exceed $25 \%$. Therefore, the $1.5 \%$ and $2.5 \%$ specimens violate the specifications.

The compressive strength of the clay bricks is determined using a compression machine under a loading rate of $0.2 \mathrm{MPa} / \mathrm{sec}$ as shown in figure 9 .

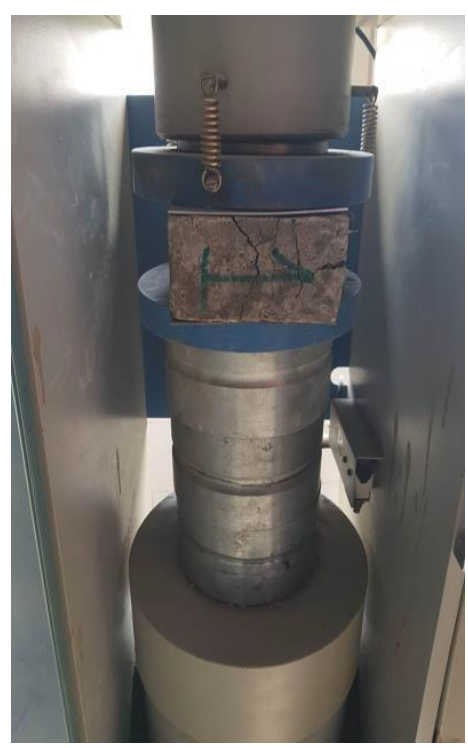

Figure 9. Samples Crushing load

The crushing load on an area of $120 \times 60 \mathrm{~mm}$ and the compressive strength are given in Table 8 . According to ESS 4763/2006, the compressive strength for non-load-bearing bricks should range between 1-8 MPa.

Table 8. Compressive strength test results

\begin{tabular}{|c|c|c|c|c|}
\hline \% SCB & $\mathbf{0 \%}$ & $\mathbf{0 . 5 \%}$ & $\mathbf{1 . 5 \%}$ & $\mathbf{2 . 5 \%}$ \\
\hline Crushing load & $2.5 \mathrm{kN}$ & $1.7 \mathrm{kN}$ & $1.5 \mathrm{kN}$ & $0.6 \mathrm{kN}$ \\
\hline Stress & $\begin{array}{c}2.123 \\
\mathrm{MPa}\end{array}$ & $\begin{array}{c}2.099 \\
\mathrm{MPa}\end{array}$ & $\begin{array}{c}2.084 \\
\mathrm{MPa}\end{array}$ & $\begin{array}{c}2.0703 \\
\mathrm{MPa}\end{array}$ \\
\hline
\end{tabular}

Table 8 reveals that the compressive strength of the specimen with no fibre additives is $2.12 \mathrm{MPa}$, while for the clay-fiber specimen with 0.5 bagasse fibres, the compressive strength is $2.09 \mathrm{MPa}$. However, the specimen with $2.5 \%$ bagasse fibres failed at $2.07 \mathrm{MPa}$. The results reveal that the compressive strength drops after burning the clay brick, which shows that the fibres have burned and reduced the compressive strength of the brick, but it is still within the acceptable range of the Egyptian code.

\section{Discussion}

The results presented in this research is consistent with the results presented by Abdullatif et al. (2020). In both studies, the compression strength of fire clay brick dropped after adding fibre waste to the specimens. However, Chan (2011), Quagliarini et al. (2010), and Salih Quagliarini et al. (2018) prove that the compression strength of clay bricks increases after adding fibres in the form of ash or after muddling clay bricks without burning the bricks [1, 3 and 26]. The resultant difference is due to the burning of fibres, which occurred during the burn 
process of the bricks.

It is recommended not to burn the clay-fiber brick and to use the old moulding and drying techniques to preserve the strength of the brick. It is noticed that using fibres in fire clay bricks reduces the surface cracks of the bricks as well as increases their thermal conductivity.

\section{Conclusions}

According to the findings, adding sugarcane bagasse fibres to clay brick at concentrations of $0.5 \%$ lowers the surface cracks and also has good compression strength under different loading conditions.

In order to achieve sustainability, the Egyptian sugar cane industry must close its material cycle. Agricultural wastes are not effectively used and are either poorly disposed or burnt, having adverse human health and environmental effects. Reusing agricultural fibre by-products contributes to sustainability. The applications range from the automotive industry to building materials. This research is an attempt to recycle sugarcane bagasse by implementing it in the production of environmentally friendly clay bricks. The proposed implementation technology is simple, low-cost, and can be applied by unskilled workers. The presented application can be widely used in many countries that face an agricultural waste disposal problem.

\section{REFERENCES}

[1] Chan C.M. "Effect of Natural Fibres Inclusion in Clay Bricks: Physico-Mechanical Properties", International Journal of Civil and Environmental Engineering, vol. 3, no. 1 , pp. 51-57, 2011

[2] Quagliarini, W., Lenci, S. and Iorio, M. "Mechanical properties of adobe walls in a Roman Republican domus at Suasa", Journal of Cultural Heritage, vol. 11, no. 2, pp. 130-137, 2010.

[3] Quagliarini, W. and Lenci, S. "The influence of natural stabilisers and natural fibres on the mechanical properties of ancient Roman adobe bricks", Journal of Cultural Heritage, vol. 11, no. 1, pp. 309-314, 2010.

[4] Kamal M.A., Moussa R.R. and Guirguis M.N., "Recycled Plastic as an Aggregate in Concrete," Civil Engineering and Architecture, vol. 9, no. 5, pp. 1289-1294, 2021. DOI: https://doi.org/10.13189/cea.2021.090502

[5] Moussa R.R., "The Reasons for Not Implementing Green Pyramid Rating System in Egyptian Buildings", Ain Shams Engineering Journal, vol. 10, no. 4, pp. 917-927, 2019. DOI: https://doi.org/10.1016/j.asej.2019.08.003.

[6] H. Alaa, N. Khaled, R. Rushdy and T. M. Hatem, "Zero Energy Educational Building: A Case Study of The Energy and Environmental Engineering Building in The British University in Egypt," 2021 IEEE 48th Photovoltaic
Specialists Conference (PVSC), 2021, pp. 1913-1915. DOI: 10.1109/PVSC43889.2021.9518995.

[7] Guirguis M.N., and Moussa R.R., "Investigation on utilizing garbage as a resource for a sustainable neighbourhood: Case study of a neighbourhood in New Cairo, Egypt", IOP Conference Series: Earth and Environmental Science, vol. 397, no. 4, 1, 012018, 2019. DOI: https://doi.org/10.1088/1755-1315/397/1/012018.

[8] Abdullatif K.G., Guirguis M.N and Moussa R.R., "Analyzing the structural properties of fire clay bricks after adding cigarette filters", WSEAS Transactions on Environment and Development, vol. 16, pp. 671-679, 2020. DOI: https://doi.org/10.37394/232015.2020.16.69.

[9] Berenguer R.A., Silva F.A.N., Monteiro E.C.B., Lins C.S. and Lima A., "Effect of Sugarcane Bagasse Ash as Partial Replacement of Cement on Mortar Mechanical Properties", Electronic Journal of Geotechnical Engineering, vol. 21, no. 14, pp. 4577-4586, 2016. Available at: ejge.com.

[10] Micheal A. and Moussa R.R., "Investigating the Economic and Environmental Effect of Integrating Sugarcane Bagasse (SCB) Fibers in Cement Bricks", Ain shams Engineering journal, vol. 12, no. 3, pp. 3297-3303, 2021. DOI: https://doi.org/10.1016/j.asej.2020.12.012

[11] Yahya M.A., Yusof M.A., Hassan Z.A., Daud N., Misnon N., Osmi S.K.C., Ridzuan N. and Yahaya, M.Y., "Usage of Sugarcane Bagasse as Concrete Retarder", International Journal of Business and Technopreneurship, vol. 3, no. 3, pp. 495-503, 2013. Retrieved from: https://www.researchgate.net/profile/Siti_Khadijah_Che_O smi2/publication/292615494_Usage_of_Sugarcane_Bagas se_as_Concrete_Retarder/links/5bd0081e299bf1a43d9c73 c9/Usage-of-Sugarcane-Bagasse-as-Concrete-Retarder.pdf

[12] Zhou X., Zheng F., Li H., and Lu C., "An environment-friendly thermal insulation material from cotton stalk fibers.”, Energy and Buildings, vol. 42, no. 7, pp. 1070-1074, 2010. DOI: 10.1016/j.enbuild.2010.01.020

[13] Roushdy M.H., "Recycling of Cullet, Waste Clay Bricks and Wastes Resulted from Wheat and Sugarcane Cultivations in the Manufacture of Fired Clay Bricks", WSEAS Transactions on Environment and Development, vol. 17, pp. 192-200, 2021. DOI: https://doi.org/10.37394/ 232015.2021.17.19”,

[14] Pappu A., Saxena M., Asolekar S.R., "Solid Wastes Generation in India and their Recycling Potential in Building Materials", Building and Environment, vol. 42, pp. 2311-2320, 2007. DOI: https://doi.org/10.1016/j.buildenv. 2006.04.015

[15] Binici, H., Aksogan, O. and Shah, T. "Investigation of fibre reinforced mud brick as a building material", Construction and Building Materials, vol. 19, no. 4, pp. 313-318, 2005.

[16] Russ, W., Mörtel, H. and Meyer-Pittroff, R. "Application of spent grains to increase porosity in bricks", Construction and Building Materials, vol. 19, no. 2, pp. 117-126, 2005.

[17] Yetgin, Ş., Çavdar, O. and Çavdar, A. "The effects of the fibre contents on the mechanic properties of the adobes", Construction and Building Materials, vol. 22, no. 3, pp. 222-227, 2008.

[18] Binici, H., Aksogan, O., Bakbak, D., Kaplan, H. and Bilge, 
I. "Sound insulation of fibre reinforced mud brick walls", Construction and Building Materials, vol. 23, no. 2, pp. 1035-1041, 2009.

[19] Sales A., and Lima S.A., "Use of Brazilian Sugarcane Bagasse Ash in Concrete as Sand Replacement", Waste Management, vol. 30, no. 6, pp. 1114-1122, 2010. DOI: https://doi.org/10.1016/j.wasman.2010.01.026

[20] Hamada Y.M., "Water Resources Reallocation in Upper and Middle Egypt", EWRA European Water, EW Publications, vol. 33: pp. 33-44, 2011.

[21] Kadir A.A., and Mohajerani A., "Physical and Mechanical Properties of Fired Clay Bricks Incorporated with Cigarette Butts: Comparison between Slow and Fast Heating Rates", Applied Mechanics and Materials, vol. 421; pp. 201-204, 2013. DOI:https://doi.org/10.4028/www.scientific.net/AM M.421.201

[22] Martirena J.F., Day R.L., Betancourt D. and Diaz Y., "Improvement of Engineering Properties of Fired Clay Bricks Through the Addition of Calcite", 7th IMC, London, 2006. Available at: https://scholar.google.com/scholar_loo kup?title=Improvement $\% 20$ of $\% 20$ engineering $\% 20$ properti es $\% 20$ of $\% 20$ fired $\% 20$ clay $\% 20$ bricks $\% 20$ through $\% 20$ the $\% 20$ addition $\% 20$ of $\% 20$ calcite\&publication_year $=2006 \&$ a uthor=J.F.\%20Martirena\&author=R.L.\%20Da\&author=D. $\%$ 20Betancourt\&author $=$ Y.\%20Diaz
[23] Dawoud N., Micheal A., and Moussa R.R., "A review on investigating the experimental process for partial replacement of cement with sugarcane bagasse in the construction industry", IOP Conference Series: Materials Science and Engineering, vol. 974, no. 1, pp. 012036, 2020. DOI: https://doi.org/10.1088/1757-899X/974/1/012036.

[24] Khedari J., Nankongnab N., Hirunlabh J., and Teekasap S., "New low-cost insulation particleboards from mixture of durian peel and coconut coir", Building and Environment, vol. 39 no. 1 , pp. 59-65, 2004. DOI: https://doi.org/10.1016/j.buildenv.2003.08.001.

[25] Loha Y.R., Sujana D., Rahmana M.E. and Dasb C.A., "Sugarcane bagasse-The future composite material: A literature review", Resources, Conservation and Recycling, vol. 75, pp. 14-22. 2013. DOI: https://doi.org/10.1016/j.res conrec.2013.03.002.

[26] ES 4763, "Building brick masonry units made from clay". Egyptian Standard Specification (ESS): Masonry building units made from desert clay used for non-load bearing walls, vol. 1234. Egypt, 2005.

[27] Salih MM., Osofero AI. and Imbabi MS., "Mechanical Properties of Fibre-Reinforced Mud Bricks". 2nd Conference of Civil Engineering. 2018. Retrived from: https://www.researchgate.net/publication/329786369_Mec hanical_Properties_of_Fibre-reinforced_mud_bricks 